\section{GIS-based Heat Demand Modelling for Tourist \\ Accommodation. A Case Study in the State of Salzburg}

GI_Forum 2020, Issue 1

Page: 107 - 118

Short Paper

Corresponding Author:

lukas.goetzlich@researchstudio.at DOI: 10.1553/giscience2020_01_s107

Lukas Götzlic h'1, Martin Sa nta Maria ${ }^{1}$, Markus Bibera cherl and Ingrid Sc ha rdinger ${ }^{1}$

${ }^{1}$ Research Studios Austria Forsc hungsgesellsc haft, Salzburg, Austria

\begin{abstract}
Spatial energy planning plays a key role in energy transition. Geo-information systems (GIS) make an important contribution in this context: spatially differentiated modelling, representation, and analysis of energy demands in the building sector are the basis for wellfounded strategic energy planning. This paper presents a GIS-based method to model the heat demand for tounist accommodation in the federal state of Salzburg. The paperincludes the development, description, implementation and validation of the heat demand modelling based on a bottom-up approach. The discussion reflects on possible improvements to the approach.
\end{abstract}

\title{
Keywords:
}

GIS model, tourist accommodation, heat demand

\section{Introduction}

Energy planning is indispensable in ensuring environmental sustainability and reducing the risk associated with climate change. The main task of energy planning is to quantify local heat demands and energy potentials, and to provide the data in a spatially differentiated form. Energy planners depend on reliable and transparent models that support them in their decision-making processes. The required depth of the models' data (spatial and temporal resolution) varies depending on the application, and energy planning normally includes additional spatially located information (e.g. building stock, supply infrastructure, energy potentials) (Mauthner, 2018). A technical and methodological challenge in creating models is to harmonize and standardize the available data to generate the greatest possible benefit.

In general, Geographic Information Systems (GIS) are suitable for processing, standardizing and visualizing several layers of information, which is why they have frequently been used in the field of energy planning for many years (Mardani et al., 2017). Improvements in data availability, data quality and computer performance enable us to conduct more context-specific analyses (including when using GIS), which often require a revision or extension of existing models or the creation of new models. 
In an existing approach to heat demand modelling by Schardinger \& Biberacher (2017), a concrete need for research into modelling the heat demand for tourist accommodation was exposed. In their project, Schardinger \& Biberacher evaluated a heat demand model at building level using the heat consumption values of regional district heating providers. In the process, significant inaccuracies were found in areas with a high share of tourist accommodation. Their additional facilities and services (e.g. swimming pools, sports facilities, saunas and laundries) produce heat demands in addition to those of room heating.

The literature offers a variety of different methods to model the heat demand. Li et al. (2017) divided the models into top-down and bottom-up ones. Bottom-up models are characterized by a higher degree of spatial and temporal detail than top-down ones. They are usually based on empirical real data ('real example building') or representative building characteristics ('real average building' or 'synthetic average building'). The necessary information for all individual buildings is often unavailable, which is why the building stock investigated is classified into building types (Ballarini et al., 2014; Loga et al., 2016), and the building models are parameterized using the characteristics of these types (Nageler et al., 2017; Schiefelbein et al., 2019; Streicher et al., 2019). The disadvantages of such bottom-up models are the high data intensity and uncertainties due to the typology (Brøgger \& Wittchen, 2018).

This paper uses an innovative bottom-up approach to model heat demand, focusing exclusively on tourist accommodation in the federal state of Salzburg. The buildings' gross floor areas ${ }^{1}$ (GFA) and the energy consumption indicator (ECI) serve as a basis for the model. The paper validates the model by comparing modelled values with reported data.

It continues the research into heat demand models for tourist accommodation and contributes to two sub-fields of energy planning: (1) mapping of buildings, and (2) heat demand modelling.

The paper has three main objectives: (1) the development, description and application of a bottom-up modelling approach for the mapping and heat demand modelling of tourist accommodation in the federal state of Salzburg; (2) the partial validation of the modelling approach developed here, using reported data; (3) the development of a data concept for the localization and characterization of the tourist accommodation stock and, based on this, a building typology for heat demand modelling. The data concept is not limited to the building type 'tourist accommodation': it is transferable to other building types because the concept is reduced to a minimum set of input parameters and relies mainly on data that is available nationwide. ArcGIS Pro v. 2.2.4 and QGIS v. 2.18 and v. 3.6 served as GIS.

The paper has the following structure. Section two provides the methodological background. First, it lists the data sources and categories used $(\$ 2.1)$, before describing the workflow (\$2.2). Section 3 provides the results, and the paper concludes with a discussion in Section 4.

\footnotetext{
${ }^{1}$ The gross floor area is defined as the sum of the aboveground and underground floor areas of a building that have to be heated or cooled during use (Amstutz \& Schegg, 2003).
} 


\section{Method}

\subsection{Data sources and categorization}

Table 1 provides an overview and a short description of the data sources used. The main data source for the model is the federal state of Salzburg. Additionally, the model integrates further building information (address, type, company, number of stars for hotels) from Herold, Bundesamt für Eich- und Vermessungswesen (BEV) and Wirtschaftskammer Salzburg (WKS).

Table 1: Data sources

\begin{tabular}{|l|l|l|l|l|}
\hline Data Source & Name & Type & Date & Description \\
\hline Salzburg State & Cadastre & Shape & 2016 & $\begin{array}{l}\text { All buildings in the federal state of } \\
\text { Salzburg as polygons }\end{array}$ \\
\hline Salzburg State & Communities & shape & 2019 & $\begin{array}{l}\text { All communities of the federal state of } \\
\text { Salzburg }\end{array}$ \\
\hline Salzburg State & DEM $^{2}$ & raster & 2016 & $\begin{array}{l}\text { DEM of the federal state of Salzburg, } \\
\text { resolution 1m }\end{array}$ \\
\hline Salzburg State & HDD 4 & raster & 2016 & $\begin{array}{l}\text { DSM of the federal state of Salzburg, } \\
\text { resolution 1m }\end{array}$ \\
\hline BEV & Addresses & csv & 2016 & $\begin{array}{l}\text { HDD for every community in the federal } \\
\text { state of Salzburg, years }\end{array}$ \\
\hline WKS & $\begin{array}{l}\text { Tourist } \\
\text { accommodation }\end{array}$ & csv & 2017 & $\begin{array}{l}\text { Tables with data about addresses, } \\
\text { buildings and types in the federal } \\
\text { state of Salzburg }\end{array}$ \\
\hline Herold & $\begin{array}{l}\text { Tourist } \\
\text { accommodation nith information about companies, } \\
\text { hotels) information about stars, in the } \\
\text { federal state of Salzburg }\end{array}$ \\
\hline
\end{tabular}

The study uses the following categories for tourist accommodation (Hotel Energy Solutions, 2011): hotels, apartments, campsites, holiday homes, inns, guesthouses, private rooms, mountain huts and youth hostels. The category 'hotel' has three sub-categories, for $2 / 3,4$ and

\footnotetext{
2 Digital Elevation Model

${ }^{3}$ Digital Surface Model

${ }^{4}$ Heating Degree Days; these represent a relationship between the room temperature and the outside temperature during the heating period and are used to find out about the heat demand. In Austria, a room temperature of $20^{\circ} \mathrm{C}$ and a temperature of $12^{\circ} \mathrm{C}$ are applied for the calculation of heat demand. This means that if the outside temperature is below $12^{\circ} \mathrm{C}$, a room has to be heated to maintain a temperature of $20^{\circ} \mathrm{C}$.
} 
5 stars (see Table 2). The paper draws on several data sources, which differ in up-to-dateness and data collection interval. In order to avoid errors, it uses the data for 2016.

\subsection{Workflow}

The starting point for building mapping and heat demand modelling is to locate all relevant buildings of the type 'tourist accommodation', as well as to allocate values for building characteristics (especially GFA). A climate-adjusted heat demand modelling at the building level is then performed, based on this information.

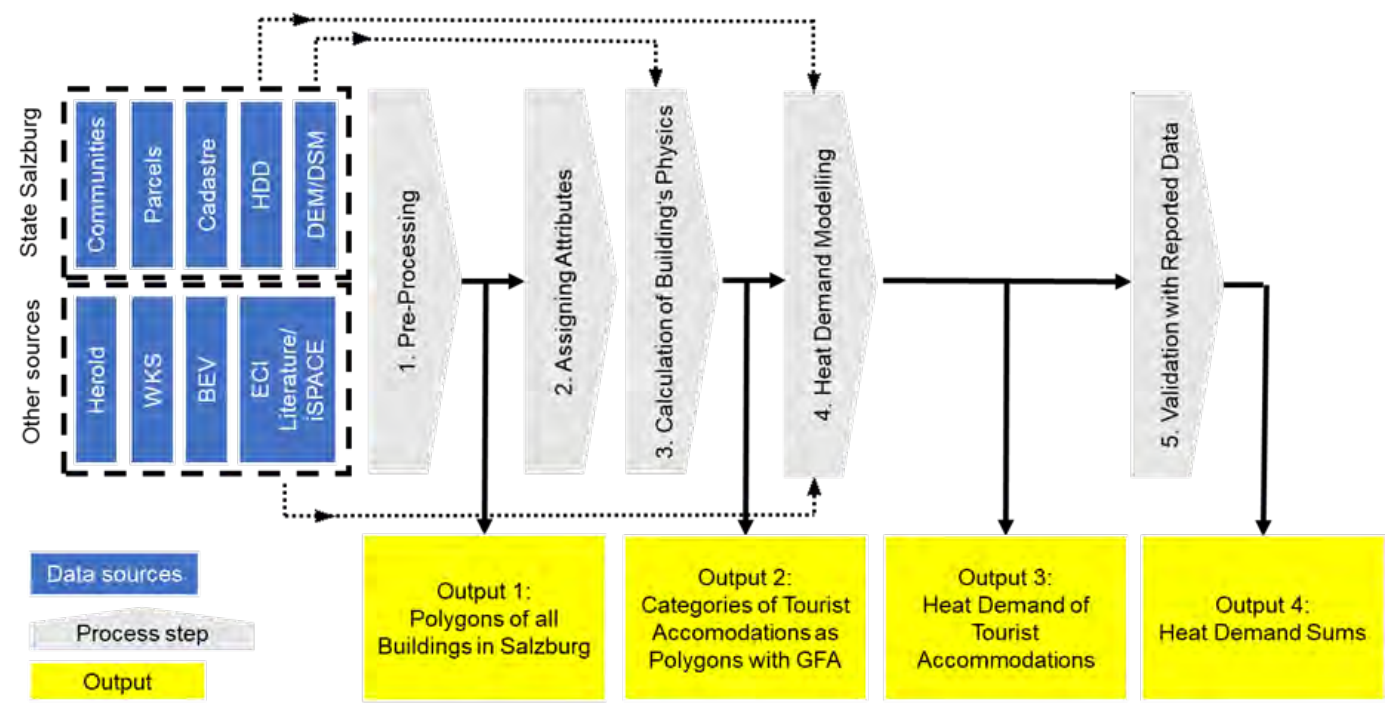

Figure 1: Workflow

Figure 1 shows the workflow used in the study, which consisted of five steps:

1. Pre-processing: In the first step, all data from the various data sources go through preprocessing to generate polygons of all buildings in the state of Salzburg as an intermediate output.

2. Assigning attributes: The polygons from step 1 are matched with all the attributes (subcategories, addresses) relevant for the model.

3. Calculation of buildings' physical characteristics: The DEM and DSM provide the height and the GFA for all tourist accommodation.

Steps 2 and 3 both pay particular attention to the buildings on the same parcel and to buildings that touch tourist accommodation, because tourist facilities tend to extend over several parcels. To prevent having to manipulate the model further, these buildings are given polygon feature classes, before a later step dissolves and transforms all feature classes of one address to a single feature class. 
4. Heat demand modelling: Step 4 comprises the heat demand modelling using ECI. The first part of the heat demand modelling is to select suitable ECIs.

The literature provides a variety of ECIs for tourist accommodation, obtained using various methods (Amstutz \& Schegg, 2003; Bayer et al., 2011; Benke et al., 2012; Perincoli et al., 2010). The ECIs differ in their categorization of tourist accommodation or their regional origin. Our paper uses a combination of ECIs from Amstutz \& Schegg (2003) and Benke et al. (2012), because of their regional proximity to the federal state of Salzburg.

Table 2 shows the final ECIs used for the categories of tourist accommodation, adapted to a reference climate 5 (for the town of Bischofshofen).

Table 2: Selected ECIs for the tourist accommodation types investigated

\begin{tabular}{|l|l|r|}
\hline \multicolumn{2}{|l|}{ Category } & Energy Consumption Indicator (ECI) in kWh/m²/a \\
\hline \multirow{4}{*}{ Hotels } & 5 stars & 156 \\
\cline { 2 - 4 } & 4 stars & 137 \\
\cline { 2 - 4 } & 3 and 2 stars & 118 \\
\cline { 2 - 4 } & No information & 125 \\
\hline Apartments & 83 \\
\hline Guesthouses & 100 \\
\hline Holiday Homes & 83 \\
\hline Inns & 131 \\
\hline Private Rooms & 83 \\
\hline Youth Hostels & 134 \\
\hline
\end{tabular}

After the selection of the ECIs, the multiplication of the GFA value by the corresponding ECI delivers the heat demand of the building. For mountain huts and campsites, no ECIs could be found, so they could not be regarded in the heat demand model.

5. Validation with reported data: In the final step, the method for heat demand modelling is compared with reported data. The validation process allows us to identify the weaknesses and strengths of the model and to avoid possible statistical errors.

The federal state of Salzburg provided heat demand data for 52 of its 119 communities, with the number of reported values varying for each community (minimum 1, with up to 344 heat demand values for any one community). These data are independent of the data used in the

${ }^{5}$ The following formula was used to calculate the appropriate ECls:

$$
\left(\frac{E l_{L_{\text {it }}}}{\mathrm{HDD}_{\text {Lit }}}\right) * \mathrm{HDD}_{\mathrm{B}^{\prime} \text { hofen }}=\mathrm{ECl}_{\mathrm{B}^{\prime} \text { hofen }}
$$




\section{Götlich et al}

heat demand modelling; hence, the comparison of these two independent datasets validates the model.

For the validation, the sums of the heat demand for the individual categories of the two datasets are compared. The heat demand sum is the sum of the heat demand of all buildings for one category and is a hypothetical value. The deviation between model and data is the parameter to evaluate the degree of agreement.

Table 3 provides an overview of the output data.

Table 3: Characteristic s of the output data sets

\begin{tabular}{|c|c|c|c|c|c|}
\hline Name & Accommodation & Extent & Buildings & Geometry & Attributes \\
\hline $\begin{array}{l}\text { Output } \\
1\end{array}$ & All & Salzburg & $\begin{array}{l}\text { Address, Parcel } \\
\text { based and } \\
\text { touching } \\
\text { buildings }\end{array}$ & Polygon & $\begin{array}{l}\text { Address, } \\
\text { Company, Type }\end{array}$ \\
\hline $\begin{array}{l}\text { Output } \\
2\end{array}$ & $\begin{array}{l}\text { Tourist } \\
\text { accommodation }\end{array}$ & Salzburg & $\begin{array}{l}\text { Address, Parcel } \\
\text { based and } \\
\text { touching } \\
\text { buildings }\end{array}$ & Polygon & $\begin{array}{l}\text { Address, } \\
\text { Company, Type, } \\
\text { Category, } \\
\text { Stars, Height, } \\
\text { GFA }\end{array}$ \\
\hline $\begin{array}{l}\text { Output } \\
3\end{array}$ & $\begin{array}{l}\text { Tourist } \\
\text { accommodation }\end{array}$ & Salzburg & $\begin{array}{l}\text { Address, Parcel } \\
\text { based and } \\
\text { touching } \\
\text { buildings }\end{array}$ & Polygon & $\begin{array}{l}\text { Address, } \\
\text { Company, Type, } \\
\text { Category, } \\
\text { Stars, Heat } \\
\text { Demand }\end{array}$ \\
\hline $\begin{array}{l}\text { Output } \\
4\end{array}$ & $\begin{array}{l}\text { Tourist } \\
\text { accommodation }\end{array}$ & Salzburg & Address & $\begin{array}{l}\text { None, } \\
\text { table } \\
\text { data }\end{array}$ & $\begin{array}{l}\text { Category, Heat } \\
\text { Demand Sums }\end{array}$ \\
\hline
\end{tabular}

\section{Results}

The results of the building mapping and heat demand modelling are a precise characterization of the building stock and its estimated heat demand. This section presents the results from outputs 2,3 and 4 . 


\subsection{Output 2: Calculation of buildings' physical characteristics}

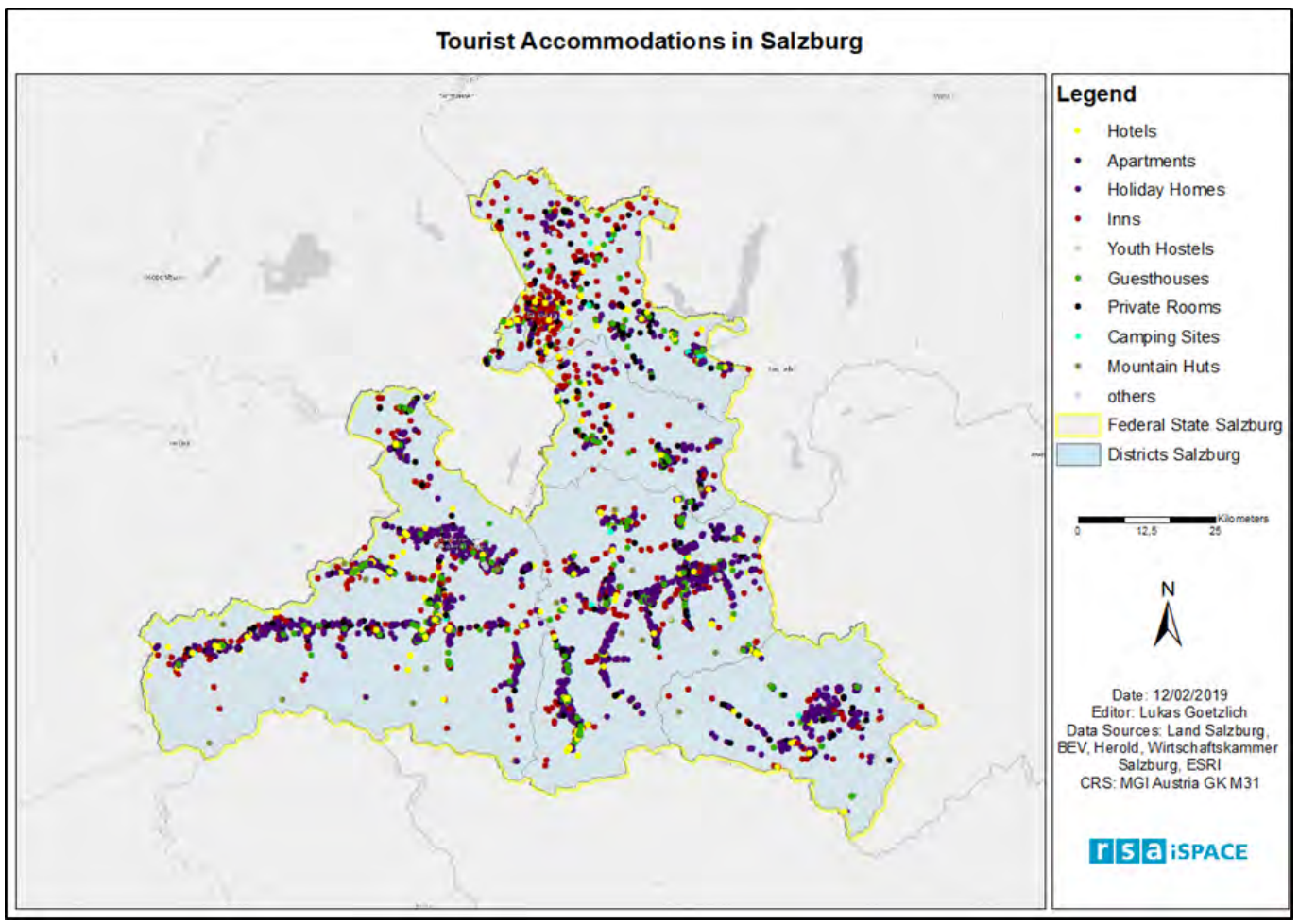

Figure 2: Tourist accommodation in Salzburg

Figure 2 shows the tourist accommodation in the state of Salzburg covered in the model. In total, 5,615 addresses and 11,125 buildings were categorized as tourist accommodation. At the district level, most of the accommodation is located in the city of Salzburg and its surroundings (1,100 addresses and 2,475 buildings), followed by the Saalbach Hinterglemm (585 buildings) and Flachau (470 buildings) districts. In terms of categories, holiday homes (1,576 addresses and 3,196 buildings) have the largest share, followed by inns (1,076 addresses and 2,639 buildings). Hotels are assigned to 802 addresses with 1,121 buildings. For about $60 \%$ of the hotels, there is no information available for the sub-categorization (number of stars). For the hotels with information, the subcategory '4-star hotel' has the largest share (170 addresses and 245 buildings). 


\subsection{Output 3: Heat demand modelling}

Heat Consumption of Tourist Accommodations - Communities Salzburg

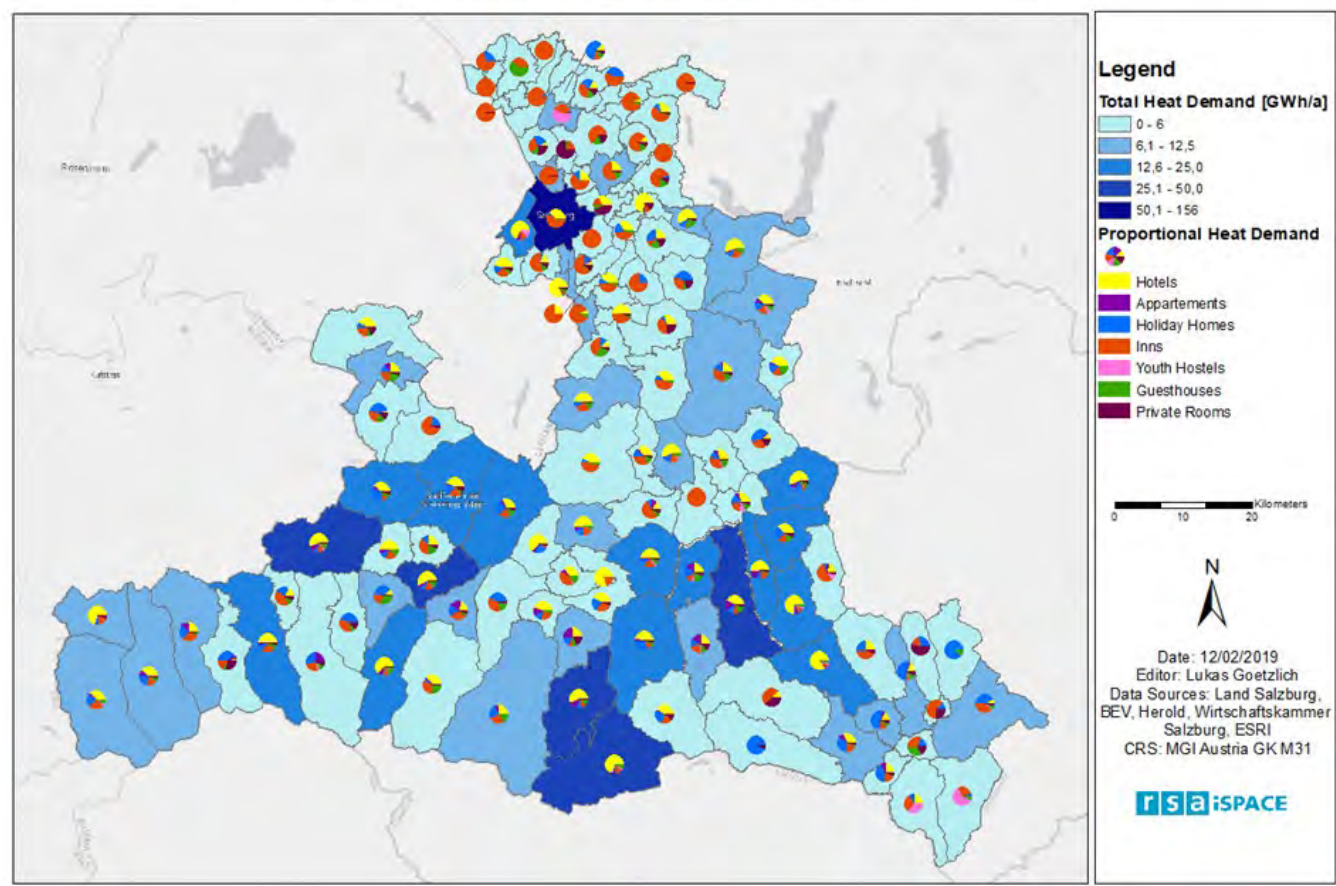

Figure 3: Heat consumption of tourist accommodation

\subsection{Output 4: Validation using reported data}

Comparision modelled vs. reported data of heat demand

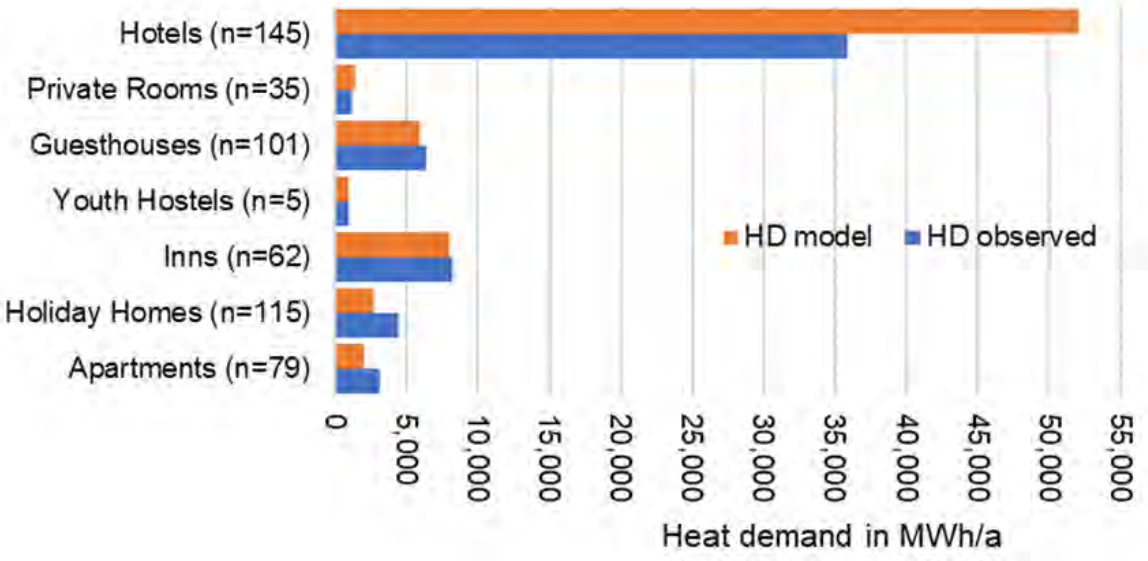

Figure 4: Comparison of modelled data vs. reported data of heat demand 
Figure 4 compares the heat demand sums of the reported and modelled data of each category. The model tends to underestimate the demand, except for the categories 'hotels' and 'private rooms'. Out of the seven categories, six show a deviation of less than $40 \%$. The largest variation is for the hotel category, although for this category the model has the highest level of detail due to the subcategories. As a result, a second validation, for the category 'hotel' only, was performed.

\section{Comparision modelled vs. reported data of heat demand}

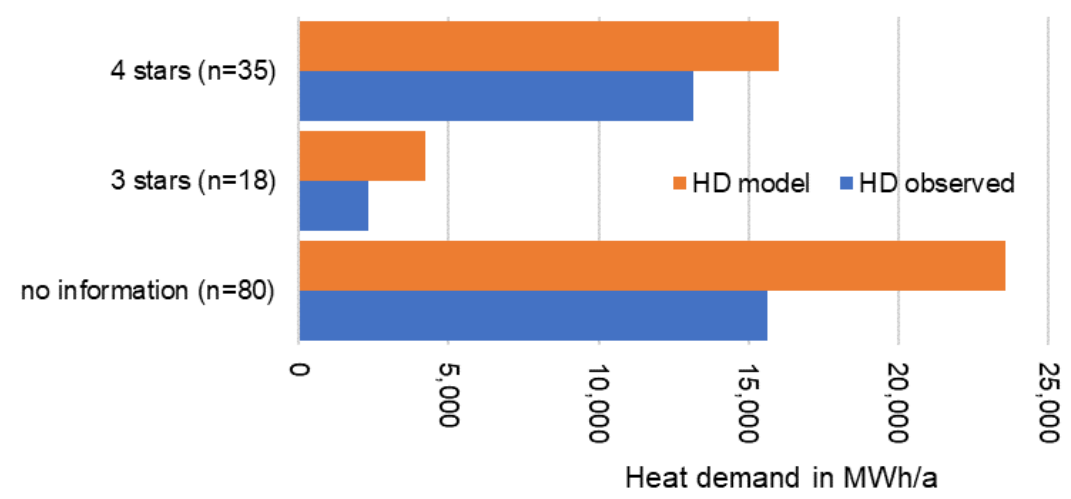

Figure 5: Comparison of modelled vs. reported data for heat demand (category 'hotel')

Figure 5 illustrates the comparison between the heat demand sums of the reported and modelled data for each sub-category of hotel. No reported values were available for the subcategory ' 2 stars'; therefore, Figure 5 does not list it. The Figure demonstrates the result from Figure 4 even more clearly, namely that the model generates excessively high values for the category 'hotel'. A further division into the subcategories '3-star' and '4-star' did not produce any additional findings.

The sample available for the validation is rather small (542 addresses with measured values from a total of 5,612 addresses in the study area). The quantitative comparison with real data has shown that the modelled heat requirements tend to underestimate the actual consumption. This finding contradicts several other studies (Bauer \& Weiler, 2013; Rehbogen et al., 2017) and may be explained by differences in user behaviour.

The results for the 'hotel' category may be systematic misinterpretations of the modelled demand vs the actual demand. Further calibration of the indicators based on real data (e.g. measurement campaigns) should be the next step for further model validation and improvements. 


\section{Discussion and outlook}

All assumptions and specifications made in the model offer the potential for improvements.

A critical point in the workflow is the assignment of attributes to buildings. All buildings on a parcel with tourist accommodation are typified as tourist accommodation, which is not necessarily true. This step is advisable because for many buildings no information is available. In the future, the quality of this information should be improved by a (preferably automated) comparison with other data sources (Google Maps, OSM, etc.). Clearly defined rules for data migration are also important to enable importing from different sources to the new schema.

The definition of the building types is an essential step in the workflow and all assignments for the building-specific heat demand modelling are based on these definitions. Established typologies from Hotel Energy Solutions (2011) were used to define the types.

Another sensitive point is the calculation of the height of the building using DEM and DSM. The study used the median value of all pixels located in the base area of a building to determine the height. One alternative parameter for the height is the mean value of all pixels.

The availability of more representative indicators for the different types of tourist accommodation can be further optimized. In particular, a calibration of the key figures based on real data (e.g. measurement campaigns) is necessary for further validations and improvements.

An alternative approach to the one presented here which uses ECI and GFA is to model the heat demand using the gross volume of the building (Kalasek \& Brus, 2018).

An essential result of our study is the description and implementation of a methodology for building mapping and heat demand modelling. The methodology includes a data concept and a definition of building typologies to model the demand using energy consumption indicators. The method was applied for the federal state of Salzburg and validated using reported data. The approach we have presented is reduced to a few input parameters, is based mainly on data available nationwide, and is therefore transferable to other building types and areas.

The validation of the model results shows that the heat demand model tends to underestimate the actual demand and that a further calibration of the model parameters is necessary. Additionally, the amount of available reported data is small.

The present paper provides a method for building mapping and heat demand modelling that is applicable more widely. The method provides an important contribution to spatial energy planning in regions with a high share of tourist accommodation (like the state of Salzburg). The findings of the paper on building mapping and heat demand modelling of tourist accommodation will be further addressed in the ongoing project S/E/P - Spatial Energy Planning for Heat Transition. ${ }^{6}$

\footnotetext{
${ }^{6}$ Website of the project: http://www.waermeplanung.at/
} 


\section{Götlich et al}

\section{References}

Amstutz, M., \& Schegg, R. (2003). Energieeffizienz und CO2-Emissionen der Schweizer Hotellerie. Bundesamt Für Energie BFE. https://www.hslu.ch/en/lucerne-university-of-applied-sciences-andarts $/$ research/projects/detail/?pid=259

Ballarini, I., Corgnati, S. P., \& Corrado, V. (2014). Use of reference buildings to assess the energy saving potentials of the residential building stock: The experience of TABULA project. Energy Policy, 68, 273-284. https://doi.org/10.1016/j.enpol.2014.01.027

Bauer, E., \& Weiler, T. (2013). Investitions- und Nutzungskosten in Wohngebäuden gemeinnütziger Bauvereinigungen unter besonderer Berücksichtigung energetischer Aspekte. Österreichischer Verband Gemeinnütziger Bauvereinigungen (Gvb), 56.

Bayer, D. G., Sturm, T., \& Hinterseer, S. (2011). Bericht über Kennzahlen zum Energieverbrauch in Dienstleistungsgebäuden. Klima- und Energiefonds im Rabmen des Programms „Neue Energien 2020 “, 27.

Benke, G., Leutgöb, K., Jandrokovic, M., Bayer, G., Baumgartner, D., Auer, M., \& Mayer, B. (2012). Energieverbrauch im Dienstleistungssektor. E7 Energie Markt Analyse GmbH, Österreichsicher Klimaund Energiefonds.

https://www.e-sieben.at/publikationen/0910_Endbericht_EV_DLG/Endbericht-EVDLG.pdf?m=1570012985\&

Brøgger, M., \& Wittchen, K. B. (2018). Estimating the energy-saving potential in national building stocks - A methodology review. Renewable and Sustainable Energy Reviews, 82, 1489-1496. https://doi.org/10.1016/j.rser.2017.05.239

Ferrari, S., Zagarella, F., Caputo, P., \& D'Amico, A. (2019). Results of a literature review on methods for estimating buildings energy demand at district level. Energy, 175, 1130-1137.

https://doi.org/10.1016/j.energy.2019.03.172

Hotel Energy Solutions. (2011). Analysis on energy use by European hotels: Online survey and desk research. Hotel Energy Solutions Project Publications.

http://www.nezeh.eu/assets/media/fckuploads/file/Reports/10.HESreserch.pdf

Kalasek, R., \& Brus, T. (2018). Berechnungsgrundlagen Heizwärmebedarf HWBsk für Gebäude (unveröffentlicht). Magistrat Der Stadt Wien MA20 - Energieplanung / TU Wien.

Li, W., Zhou, Y., Cetin, K., Eom, J., Wang, Y., Chen, G., \& Zhang, X. (2017). Modeling urban building energy use: A review of modeling approaches and procedures. Energy, 141, 2445-2457. https://doi.org/10.1016/j.energy.2017.11.071

Loga, T., Stein, B., \& Diefenbach, N. (2016). TABULA building typologies in 20 European countriesMaking energy-related features of residential building stocks comparable. Energy and Buildings, 132, 4-12. https://doi.org/10.1016/j.enbuild.2016.06.094

Mardani, A., Zavadskas, E. K., Khalifah, Z., Zakuan, N., Jusoh, A., Nor, K. M., \& Khoshnoudi, M. (2017). A review of multi-criteria decision-making applications to solve energy management problems: Two decades from 1995 to 2015. Renewable and Sustainable Energy Reviews, 71, 216-256. https://doi.org/10.1016/j.rser.2016.12.053

Mauthner, F. (2018). Vergleich von GIS-basierten Methoden zur Kartierung von Wärmebedarfen-Grundlagen räumlicher Energieplanung am Beispiel der Stadtgemeinde Gleisdorf.

https://doi.org/10.13140/RG.2.2.25449.0368 


\section{Götlich et al}

Nageler, P., Zahrer, G., Heimrath, R., Mach, T., Mauthner, F., Leusbrock, I., Schranzhofer, H., \& Hochenauer, C. (2017). Novel validated method for GIS based automated dynamic urban building energy simulations. Energy, 139, 142-154. https://doi.org/10.1016/j.energy.2017.07.151

Perincoli, L., Hotelleriesuisse, 3003 Bern, Bundesamt für Energie BFE, 3003 Bern, \& Energie-Agentur der Wirtschaft, 8032 Zürich. (2010). Energiemanagement in der Hotellerie. Leiffaden Energiemanagement in Der Hotellerie, 3. Auflage(Ing. Büro Energie \& Umwelt). http://www.hotelpower.ch/sites/default/files/eidh_d_wkom_link_0.pdf

Rehbogen, A., Strasser, H., Koblmüller, M., Mostegl, N., Schardinger, I., \& Biberacher, M. (2017). Integrierter Wärmeplan Zentralraum Salzburg-Umsetzungsplanung für die Wärmewende der EnergieVorzeigeregion Salzburg (heatswap_Salzburg). https://www.vorzeigeregion-energie.at/projekt/heatswap_salzburg/

Reinhart, C. F., \& Cerezo Davila, C. (2016). Urban building energy modeling - A review of a nascent field. Building and Environment, 97, 196-202. https://doi.org/10.1016/j.buildenv.2015.12.001

Schardinger, I., \& Biberacher, M. (2017). Fernwärmepotenzial im Bundesland Salzburg. Interner Projektbericht. Im Auftrag Des Amtes Der Salzurger Landesregierung. - Salzburg.

Schiefelbein, J., Rudnick, J., Scholl, A., Remmen, P., Fuchs, M., \& Müller, D. (2019). Automated urban energy system modeling and thermal building simulation based on OpenStreetMap data sets. Building and Environment, 149, 630-639. https://doi.org/10.1016/j.buildenv.2018.12.025

Streicher, K. N., Padey, P., Parra, D., Bürer, M., Schneider, S., \& Patel, M. (2019). Analysis of space heating demand in the Swiss residential building stock: Element-based bottom-up model of archetype buildings. Energy and Buildings, 184, 300-322.

https://doi.org/10.1016/j.enbuild.2018.12.011 